\title{
O Pan-Africanismo e o Pan-Arabismo. A Organização para a Unidade Africana e a QUESTÃo PALESTINA (1967-1975)
}

\author{
The pan-Africanism and pan-Arabism. The Organization of African Unity and the Palestine \\ QUESTION (1967-1975)
}

Fabio Bacila Sahd* fabiobacila@hotmail.com

RESUMO: O presente trabalho discute o posicionamento da Organização para a Unidade Africana em relação a Israel e à Questão Palestina, fundamentando-se em suas resoluções e naquelas da Organização das Nações Unidas. Busca-se traçar a aproximação entre pan-arabismo e panafricanismo, a evolução dos debates sobre o Oriente Médio no seio da OUA e compreender o que a teria levado a se solidarizar com a Questão Palestina e a considera-la, em 1975, literalmente uma "causa africana". O recorte analisado é balizado pelo início da ocupação dos territórios árabes por Israel, que marcou uma virada nas relações da África com esse país, e pela aprovação da resolução 3379 da Assembleia Geral da ONU, em 1975, apoiada amplamente pelos membros africanos, que considerou o sionismo uma forma de racismo.

PALAVRAS-ChAVE: Organização para a Unidade Africana, Palestina, Pan-africanismo.

ABSTRACT: This paper discusses the position of the Organisation for African Unity in relation to Israel and the Palestine Question, basing on its resolutions and those of the United Nations. We seek to outline the approach of pan-Arabism and pan-Africanism and the debates on the Middle East within the OAU and understand what would have led it to show solidarity with the Palestinian Question and considers it literally in 1975 one African cause. The analysis is temporal limited by the occupation of Arab territories by Israel, which marked a turning point in the relations of Africa with that country, and the adoption of resolution 3379 of the UN General Assembly in 1975, widely supported by African members, which considered Zionism a form of racism.

KEYWORDS: Organization of African Unity, Palestine, pan-Africanism.

\section{A Organização para a Unidade Africana}

A fundação da Organização para a Unidade Africana (OUA) está vinculada ao surgimento e à difusão do pan-africanismo no século $X X$, como movimento político e cultural que considera a África, os africanos e seus descendentes mundo afora como um

\footnotetext{
* Doutorando no curso interdisciplinar de ciências humanas ("Humanidades, direitos e outras legitimidades") da Universidade de São Paulo (USP)
} 
conjunto único e objetiva "regenerar e unificar" o continente, fortalecendo o sentimento de solidariedade entre seus povos. De uma ideologia reformista e protestante, surgida dos afrodescendentes nos Estados Unidos, o pan-africanismo foi incorporado na África e transformado em um movimento de massas, nacionalista e orientado para a libertação do continente. A OUA foi a culminância de sua força de integração e emancipação, características que se sobressaíram a partir de 1935, enrobustecendo-se com o final da Segunda Guerra. Foram fundamentais nessa propagação a atuação de Kwame Nkrumah, George Padmore e Alioune Diop e a fundação da Presénce africaine, movimento cultural que recuperava os fundamentos do pan-africanismo, defendendo o florescimento da cultura negra e a união e solidariedade nas lutas anticoloniais.

Entre a independência de Gana, em 1957, e a fundação da OUA, em 1963, a partir da união de alguns países e das conferências dos Estados independentes e dos Povos Africanos, o movimento pan-africano e seus esforços de integração foram assumindo uma forma mais definida. Malgrado as divergências entre os países quanto aos limites da integração e à salvaguarda das soberanias individuais, o consenso em relação ao não alinhamento e à necessidade de intensificar a luta política pela descolonização plena possibilitou a crescente aproximação e ação conjunta dos blocos opostos, visto terem uma plataforma comum. Mesmo fragmentados entre pró-capitalistas e pró-socialistas e entre revolucionários, progressistas, reacionários e moderados, os Grupo de Casablanca e de Monróvia consentiram na criação de uma organização que traduzisse as demandas mínimas do pan-africanismo ${ }^{1}$. Apesar da frustração pela OUA não expressar o desejo de uma união política e econômica sistêmica e abrangente dos países africanos, as lideranças mais a esquerda não se retiraram da entidade, optando por debater essas dissensões em seu seio.

Se por um lado, os novos dirigentes africanos estavam em desacordo em relação à natureza da integração política que devia ser realizada na África, era quase unânime o reconhecimento da urgente necessidade em libertar inteiramente o continente do colonialismo; os Grupos da Monróvia e da Casablanca continuaram fiéis ao seu compromisso histórico em favor do não alinhamento e da libertação completa das últimas colônias. Esta adesão geral em prol da libertação é realmente uma das razões, senão a principal delas, da unificação dos grupos que formaram a OUA logo após um memorável encontro em Addis-Abeba, em maio de 1963 (KODJO; CHANAIWA, 2010, p. 902).

\footnotetext{
${ }^{1}$ Enquanto o primeiro reuniu Gana, Guiné, Egito, Mali, Marrocos, Líbia e o governo argelino no exílio, o segundo congregou Nigéria, Etiópia, Libéria, Serra Leoa e algumas das ex-colônias francesas.
} 
$\mathrm{Na}$ apresentação da carta da OUA - elaborada em consonância com a Declaração Universal dos Direitos Humanos (DUDH) e com a carta da Organização das Nações Unidas (ONU) -, são evidenciados os princípios que embasaram sua fundação. Destacam-se a conviç̧ão de que "controlar seu próprio destino é um direito inalienável de todos os povos", a consciência de que "liberdade, igualdade, justiça e dignidade são objetivos essenciais para a realização das legítimas aspirações dos povos africanos" e a "responsabilidade de empregar os recursos humanos e naturais do continente" para o desenvolvimento dos africanos. Paralelamente a esses princípios, estão: a promoção da compreensão, cooperação, irmandade e solidariedade entre os povos e Estados a partir de uma unidade que transcenda diferenças étnicas e nacionais, a salvaguarda e consolidação das independências, soberania e integridade territorial dos Estados e a "luta contra o neocolonialismo em todas as suas formas". O caráter fundamentalmente anticolonial da OUA também fica evidente em alguns artigos de sua carta. Seus objetivos são assim definidos: promover a unidade e solidariedade dos Estados Africanos, defendendo sua soberania, integridade territorial e independência; coordenar e intensificar os esforços para conseguir uma vida melhor para os povos da África; erradicar todas as formas de colonialismo do continente e promover a cooperação internacional, baseada na carta da ONU e na DUDH. Para isso, os Estados membros são instados a coordenar e harmonizar suas políticas, fortalecendo a cooperação diplomática, econômica, sanitária, nutricional, cultural, educacional, científica, técnica, defensiva e securitária. Todos devem "dedicação absoluta à emancipação completa dos territórios africanos, que ainda são dependentes" (NALDI, 1989).

Ainda que a OUA visasse fortalecer e coordenar a cooperação de seus membros em outros campos e defender os direitos humanos no continente, seus objetivos eram, fundamentalmente, políticos e anticoloniais. A preservação do colonialismo era considerada "uma flagrante violação dos direitos inalienáveis dos legítimos habitantes dos respectivos territórios e representava uma ameaça para a paz continental". Para suprimilo, relações diplomáticas e comerciais foram cortadas (a exemplo da África do Sul, Portugal e, posteriormente, Israel) e foi criado o Comitê de Libertação da OUA, encarregado de aumentar a combatividade, confiança e determinação dos movimentos, uni-los, traçar estratégias de luta, treinar e abastecer os militantes e coordenar a ajuda fornecida pelos Estados africanos ao fundo de libertação. Internacionalmente, a Organização foi responsável por chamar a atenção e mudar a atitude dos países em relação ao colonialismo. Ela conseguiu sua condenação junto com a do racismo pela ONU, especificamente o apartheid, e garantir a legitimidade e o apoio moral e material das Nações Unidas para os movimentos de libertação (resolução 2555 da Assembleia Geral). Sob a influência dos Estados africanos recém-independentes e dos demais membros do 
Terceiro-Mundo, a ONU passou de "potência imperial coletiva" à aliada das lutas de libertação (KOUASSI, 2010, p. 1090). Dado as alianças terceiro-mundistas da época, que reforçaram a posição desses países no globo, se a OUA reconhecia oficialmente um movimento de libertação e seus dirigentes estes eram reconhecidos internacionalmente. Ao contrário, seu não reconhecimento (a exemplo dos regimes racistas no Zimbábue, Namíbia e África do Sul) culminava em boicotes. Potências, inclusive a OTAN como um todo, foram corriqueiramente condenadas pelo suporte prestado a regimes colonialistas ou racistas.

A carta da OUA acabou por definir uma ética política de cunho pan-africano, que propõe aos Estados membros um conjunto de princípios destinados a reforçar sua unidade e solidariedade. Nos artigos concernentes à estrutura da Organização é possível observar a prevalência dos fundamentos do Grupo de Monróvia - criação de uma "confederação 'maleável' de Estados africanos", que participam e cooperam de forma voluntária, garantindo a soberania e a integridade territorial de cada país e a não ingerência em assuntos internos (ASANTE; CHANAIWA, 2010). O documento também prevê o tratamento pacífico das contendas, por meio de negociações, mediação, conciliação ou arbitragem e condena sem reservas o assassinato político e as atividades subversivas (KODJO; CHANAIWA, 2010).

Concretamente falando, a primeira década da campanha anticolonial da OUA está marcada pelos primórdios da luta armada. Suas atividades no período foram, sobretudo, a organização do Comitê de Libertação e dos movimentos nacionais, o treinamento militar e a publicação de declarações de princípio e manifestos. A partir de 1973, seus esforços produziram resultados consistentes, possibilitando aos nacionalistas conduzir as guerras que libertaram, progressivamente, grande parte das colônias, bem como reorganizar a administração pública e a economia (KODJO; CHANAIWA, 2010, p. 924). Contrapondo-se a essa visão entusiasta dos sucessos da OUA, outros autores destacam a debilidade da Organização e de suas estratégias de libertação, não obstante a sinceridade de seu posicionamento (SESAY; OJO; FASEHUN, 1984). Dentre as principais causas dessa fragilidade estariam a pobreza dos Estados membros, sua incapacidade de subvencionar as lutas em um grau satisfatório e, sobretudo, as divisões típicas da Guerra Fria entre países conservadores, vinculados ao Ocidente e dúbios no apoio aos movimentos de libertação, e regimes progressistas, o que teria limitado a abrangência e a intensidade das ações coletivas. Na perspectiva mais otimista de Kodjo e Chanaiwa, estas divergências não teriam obliterado o amplo apoio à libertação continental.

Antes de passarmos na sequência à análise das relações entre pan-africanismo e pan-arabismo e das resoluções da OUA, cabe nos determos um pouco na estrutura dessa 
organização. Seu órgão supremo era a Conferência dos Chefes de Estado e de Governo, que se reunia em sessão ordinária uma vez ao ano e elegia a cada assembleia uma mesa dirigida por um presidente, que se tornou, ao longo dos anos, o presidente de facto. $\mathrm{O}$ outro órgão era o Conselho dos Ministros, que se reunia duas vezes por ano em sessão ordinária e estava voltado, essencialmente, às questões administrativas e financeiras. 0 Conselho preparava os encontros dos chefes de Estado e assegurava a continuidade de suas decisões.

\section{O encontro do pan-arabismo com o pan-africanismo}

O pan-arabismo e o pan-africanismo apresentam afinidades estruturais e ideológicas, que se vinculam à expansão colonialista, à situação periférica dos países africanos e árabes no sistema capitalista mundial e ao discurso racista-colonialista, que legitimou a dominação da periferia mundial pelo centro (ou do sul pelo norte). Assim como o léxico e as estratégias empregadas na África e na Ásia pelas potências coloniais não diferiram muito entre si, as resistências que geraram entre os nativos também foram semelhantes. Os princípios comuns que aproximaram a África da "Questão Árabe" e "Palestina" estiveram presentes muito antes da fundação da OUA. O anticolonialismo que mobilizou as lideranças africanas com mais contundência após a Segunda Guerra Mundial criou pontes com as questões médio-orientais - primeiramente ideológicas e depois políticas, econômicas e diplomáticas -, haja vista a reiteração desse mesmo referencial na luta dos árabes contra Israel e a pertença do norte da África a esses dois mundos. As resoluções das primeiras conferências dos Estados Africanos Independentes e das conferências dos povos africanos indicam os fundamentos desse "destino comum", posteriormente reconhecido oficialmente pela OUA.

Assim como no mundo árabe, as preocupações dos líderes africanos giraram em torno do colonialismo e das guerras de libertação. Dentre as estratégias que traçaram contra o imperialismo, colonialismo e racismo estavam: apoiar os movimentos de libertação e o direito à autodeterminação dos territórios e povos colonizados; formar uma frente única no seio da ONU; e solidificar a união africana e resguardar a África das fissuras provocadas pela Guerra Fria, afirmando a política do não alinhamento. A luta pela libertação acabaria por aproximar ainda mais a OUA da Questão Palestina, dado o crescente interesse e defesa dos direitos humanos e internacionais, como a autodeterminação. Edem Kodjo e David Chanaiwa (2010) consideram que, a aproximação entre pan-arabismo e pan-africanismo ocorreu após a Segunda Guerra, sobretudo a partir da polivalência de Sudão, Egito, Marrocos, Argélia, Tunísia e Líbia, componentes tanto da 
África quanto do mundo árabe. A Revolução Egípcia, em 1952, teria acelerado esse encontro, mormente a partir da teoria de Gamal Abdel Nasser da pertença egípcia a três círculos concêntricos: o mundo árabe, muçulmano e africano. Em sua visão, o combate ao imperialismo ocidental e ao sionismo perpassava essas esferas, portanto, seu país e povo não podiam ficar indiferentes às lutas ao sul do Saara. Essa concepção anticolonial mais ampla fez confluir no Cairo militantes, dissidentes e movimentos nacionalistas árabes e africanos, que com o apoio estatal e da rádio Le Caire (que difundia internacionalmente as ideias dos revolucionários) costuraram alianças e prepararam revoluções. Aproximando árabes e africanos, Nasser desempenhou um papel "subversivo", não só no Oriente Médio como no conjunto da África Subsaariana, o que Ihe rendeu a oposição e invasão das expotências regionais, França e Inglaterra. Tornado herói dos direitos árabes e africanos, a reputação de Nasser aumentou ainda mais com a nacionalização do Canal de Suez e a vitória política conseguida em 1956, quando apesar do sucesso militar de Israel, França e Inglaterra sobre o Egito eles tiveram que se retirar dos territórios ocupados sem lograr nenhuma vantagem. Nasser demonstrara então que, o imperialismo não estava tão forte como outrora e que era possível, tirando proveito dessa fraqueza, a libertação das nações oprimidas da África e alhures (KODJO; CHANAIWA, 2010).

Além dos círculos árabe, islâmico e africano, destaca-se a atuação proeminente do Egito junto aos países não alinhados ou Terceiro Mundo, que remonta já à Conferência de Bandung em 1955. A participação egípcia nesse meio foi fundamental para seu crescente protagonismo nos assuntos mundiais. Paradoxalmente, nesse mesmo contexto, Nasser estrategicamente se aproximou da URSS, devido ao crescente apoio "ocidental" a Israel e ao não fornecimento de armas análogo ao Egito, o que levou a tratados com os países socialistas para abastecer seu país. Nessa correlação de forças, a partir de meados dos anos 1950, Nasser compôs o núcleo da oposição ao Pacto de Bagdá - política delineada pelos Estados Unidos e Grã-Bretanha que visava o alinhamento de Estados médio-orientais junto ao "Ocidente" (HRBEK, 2010, p. 168-174). A despeito dessa ambiguidade característica do Terceiro Mundo, "no longo prazo, a filosofia do não alinhamento veio reforçar a convergência de interesses dos mundos árabe e africano, ambos preocupados com um possível questionamento dos seus interesses externos" (EDMONDSON, 2010, p. 1028). A solidificação desses laços se deveu, em boa medida, à determinante influência exercida pelo Egito que, desde a ascensão de Nasser e a "vitória" de 1956 até a assinatura dos acordos de paz com Israel no final dos anos 1970, criou pontes entre a África e o mundo árabe e asiático. Se Bandung garantiu uma tomada de consciência da unidade do Terceiro-Mundo, a conferência de cúpula dos países não alinhados, realizada em Argel no ando de 1973, reforçou sobremaneira esse sentimento. A pertença dos países africanos e árabes "ao Grupo dos Setenta e Sete e a sua participação nas negociações Norte-Sul 
constitui, por outro lado, a origem de uma aliança mais ampla com o restante do Terceiro-Mundo, aliança esta que tem recentemente adquirido uma nova dimensão" (KODJO e CHANAIWA, 2010, p. 921).

Concomitantemente ao impulso dado pela política nasserista e ao não alinhamento, outros fatores concorreram para a aproximação árabe-africana, como a Guerra da Argélia que, a partir da independência de Gana em 1957, gradativamente deixou de dividir o continente africano entre a rejeição ao colonialismo e a amizade de alguns com a França (o que se refletia na pertença ao Grupo de Casablanca ou de Monróvia). O apoio de Gana, Guiné e Mali ao governo argelino no exílio e a corroboração da denúncia árabe da política israelense como neocolonial e representante do Ocidente tiveram repercussões positivas na formação da aliança pan-africanismo/pan-arabismo. A unidade africana nesses pontos foi ainda mais cimentada no início dos anos 1960, com a independência da Argélia e criação da OUA, afro-árabe em sua composição e objetivos.

Ainda na década de 1960, a Guerra dos Seis Dias em 1967 foi fundamental na conformação da frente árabe-africana anti-imperialista, consolidada a partir da Guerra do Yom Kippur, em 1973, quando quase todos os países africanos romperam relações diplomáticas com Israel. A conquista israelense da Península do Sinai foi considerada agressão contra um membro da OUA e ocupação de parte do continente, o que "africanizou" o conflito e recrudesceu a aliança e solidariedade afro-árabe. Esses vínculos se reforçaram ainda mais com a participação comum de países árabes e africanos na OUA, na Organização da Comunidade Islâmica, na Organização dos Países Exportadores de Petróleo e no bloco dos países não alinhados (Grupo dos Setenta e Sete) e Terceiro Mundo. A Crise do Petróleo, logo após a Guerra de 1973, reforçou essa aproximação, sedimentando uma colaboração de dimensão até então inédita. Foi nesse momento que a OUA, por meio de seu Conselho de Ministros, criou um comitê de sete membros para contatar a Liga Árabe e estabelecer uma política de cooperação, o que resultou na criação do BADEA (Banco Árabe para o Desenvolvimento Econômico da África ainda em 1973) e, no ano seguinte, do Fundo Especial de Ajuda à África, do Fundo Árabe de Assistência Técnica aos Estados Árabes e Africanos e na aprovação de uma declaração e de um programa de ação relativo à cooperação mútua. Com alguns membros em comum, e na condição de "primeiras organizações (regionais) criadas e dirigidas pelas nações pobres, para as nações pobres do mundo", a OUA e a Liga Árabe expressaram a solidariedade afroárabe vislumbrada por Nkrumah e Nasser já nos anos 1950, complementando-se em vários aspectos além da cooperação internacional. A Liga Árabe, "'núcleo do grupo afro-asiático' durante os anos 1950, encontrava-se fortalecida pela OUA quando ela 'começava a perder o seu dinamismo juvenil'" (EDMONDSON, 2010, p. 1028). 
Ao lado da Guerra dos Seis Dias e da ocupação do Sinai, a cooperação de Israel com o regime de apartheid na África do Sul foi central para consolidar o afastamento entre os países africanos e Israel, sobretudo após 1973. As lutas anticoloniais travadas no continente, especialmente nas colônias portuguesas, na Argélia e na região austral, tornaram-se internacionais, envolvendo a participação ativa de diferentes atores, com suporte financeiro, fornecimento de armas e até envio de tropas. No cenário da Guerra Fria, enquanto a URSS e seus aliados prestaram apoio fundamental aos movimentos de libertação, Israel e os membros da OTAN subvencionaram regimes colonialistas e racistas, o que inclusive foi percebido e condenado pela OUA em diversas ocasiões. Por exemplo, especialmente nos anos 1970, enquanto Cuba apoiou as resistências, instruiu combatentes africanos das forças de libertação e ofertou serviços de treinamento agrícola, sobretudo em Angola e na África do Sul, Israel "se conduziu de fato na qualidade de aliado do regime de supremacia branca", formando tropas contrarrevolucionárias e colaborando militarmente com o regime de Pretoria, inclusive em seu programa nuclear (EDMONDSON, 2010, p. 1038).

Destarte, a intensa solidariedade e cooperação afro-árabe também podem ser explicadas pela existência de um inimigo comum: a identificação entre apartheid e sionismo. Os opositores de ambos constituíram uma força política única no seio das organizações internacionais, como a OUA e a ONU, o que levou ao crescente isolamento de Israel e a aprovação de resoluções condenatórias, como a 3379 (considerando o sionismo racismo). Enquanto os árabes cortaram relações e boicotaram a África do Sul os países africanos fizeram o mesmo em relação a Israel, uns estritamente por afinidade ideológica e outros, mais a direita no espectro político, contando com auxílio econômico. Edmondson (2010) critica alguns autores que interpretam esse isolamento israelense como capitulação africana diante da "arma do petróleo" árabe. Seriam análises feitas de "forma cínica e contrária à verdade histórica", que deformariam "a cronologia dos acontecimentos", visto uma boa parte do continente "estar posicionada ao lado dos árabes no tocante à questão da Palestina, bem anteriormente à incidência do fator petrolífero" ${ }^{2}$. Os cortes das relações diplomáticas com Israel decorreriam de um "novo espírito de solidariedade política" e da percepção de convergências de interesses. Ao passo que a Organização Africana criticava e ameaçava boicotar Israel, a Liga Árabe, no final de 1973, optava pela abertura de três

\footnotetext{
${ }^{2}$ Embora Edmondson não cite nomes, um autor que podemos incluir nesse rol é Joel Peters. Embora afirme a concorrência de vários fatores para a ruptura massiva das relações diplomáticas entre os países da África e Israel, ao final de sua análise acaba por enfatizar como determinantes os aspectos econômicos e a pressão e propaganda árabe e soviética sobre os africanos. Cf: PETERS, Joel. Israel and Africa: the problematic friendship. London: I.B. Tauris \& Co Ltd, 1992.
} 
instituições para promover a cooperação econômica com o continente africano e impunha um embargo a Portugal colonialista e aos regimes racistas da Rodésia e África do Sul ${ }^{3}$.

\section{A OUA, o Oriente Médio e a Palestina}

Se desde a fundação de Israel até a primeira metade da década de 1960 prevaleceram relações amistosas com alguns países da África - a exemplo de consultorias agrícolas e empresas conjuntas em vários países -, estas se desintegrariam a partir da Guerra dos Seis Dias e da aproximação entre sionismo, colonialismo português e apartheid $^{4}$ (CHANAIWA, 2010; OWUSU, 2010). Até que o peso desses eventos determinantes fosse sentido e provocasse uma redefinição das relações políticodiplomáticas no final dos anos 1960 início dos anos 1970, essa fértil cooperação pregressa entre Israel e a África fez com que a OUA nos primeiros anos de sua existência permanecesse dissociada das questões médio-orientais, não obstante os esforços de seus membros árabes para envolver diretamente a Organização Africana e sua proximidade ideológica com a Liga Árabe. Os laços anteriores haviam fincado raízes, mas não profundas o suficiente para resistir ao impacto gerado pela ocupação de um território africano por Israel e pelo vínculo com o racismo no sul do continente (EDMONDSON, 2010).

Analisando as fontes, nota-se que gradativamente, a partir da Guerra dos Seis Dias, a Questão Palestina foi sendo inserida na agenda de discussões da OUA como item dissociado da questão maior médio-oriental. Se, inicialmente, a Organização Africana enfatizou a situação dos territórios egípcios ocupados por Israel em 1967 - devido à própria participação desse país em seu seio - e a necessidade de libertá-los, do começo dos anos 1970 em diante passou a discutir especificamente a situação da Palestina, continuando a fazê-lo mesmo após o acordo de paz entre o Egito e Israel, no final da década, que culminou com a retirada e devolução da Península do Sinai até então ocupada. Na Quarta Sessão Ordinária da Assembleia dos Chefes de Estado e Governo, realizada na cidade de Kinshasa (Congo), entre onze e quatorze de setembro de 1967 (portanto três meses após a guerra entre árabes e israelenses), foi aprovada uma declaração afirmando o princípio de respeito à soberania e à integridade territorial dos

\footnotetext{
${ }^{3}$ Apesar dessa extensa e inédita cooperação entre árabes e africanos, inserida no âmbito das relações terceiro-mundistas, ela foi limitada por algumas perspectivas e prioridades políticas divergentes. A título de exemplo, a Liga Árabe não conseguiu convencer a OUA a excluir o Egito de seu próprio quadro de membros, após ele ter reconhecido Israel em 1979, e a apoiar a expulsão do Estado sionista da ONU.

${ }^{4}$ Ainda que as relações amigáveis entre Israel e a África do Sul tenham permanecido sólidas assim como o apoio incondicional dos africanos à Questão Palestina, o reconhecimento de Israel pelo Egito abalou essa política de bloco dos países africanos em relação ao Estado sionista.
} 
Estados membros. Na ocasião, a OUA demonstrou sua preocupação com a grave situação prevalecente na "República Árabe Unida" (RAU, atualmente Egito), "um país africano cujo território está parcialmente ocupado por um poder estrangeiro", expressou sua simpatia pelo país e decidiu trabalhar junto à ONU para assegurar a evacuação do território ocupado (ORGANIZATION OF AFRICA UNITY, 1967).

Na reunião ordinária seguinte, realizada em Argel em 1968, ao invés de uma declaração, a Assembleia dos Chefes de Estado e Governo da OUA aprovou uma resolução após ouvir uma exposição do Ministro das Relações Exteriores da RAU sobre a questão como um todo. A Organização então reafirmou seu apoio e clamou a retirada das tropas israelenses não só da Península do Sinai (como anteriormente), mas de todos os territórios ocupados, desde a guerra de 1967. Ademais, pediu aos membros que trabalhassem para garantir a estrita implementação da resolução 242 do Conselho de Segurança da ONU, que ao demandar a retirada dos territórios e um acordo geral para uma paz justa e duradoura serviu de base para essa decisão africana. Essa abordagem mais ampla da questão já havia sido feita no final de fevereiro de 1968, na décima sessão ordinária do Conselho dos Ministros da OUA. Na ocasião, os árabes foram tratados como "vítimas da agressão sionista" e foi jurada solidariedade ativa a sua "justa causa", sendo os membros da OUA convocados a dar apoio político, moral e material a eles.

Em setembro de 1969, na sexta reunião ordinária da Assembleia dos Chefes de Estado e Governo da OUA, foi aprovada uma resolução sobre "a agressão das forças israelenses contra a RAU". Em suas linhas é possível perceber a preocupação da entidade sobretudo com o território egípcio. No calor de "mais uma agressão perpetrada pelas forças israelenses contra outra parte do território nacional da República Árabe Unida", a Organização reafirmou novamente sua solidariedade, condenou esse ato específico ("como todos os outros atos de agressão direcionados a um país irmão") e apelou à consciência da humanidade para fazer o possível para poupar "nosso continente, que têm sofrido muito frequentemente com invasões de forças estrangeiras, de se tornar palco de tensão e conflito". Na reunião do Conselho dos Ministros da OUA, realizada no começo de 1969, a convocação foi para os Estados membros auxiliarem na promoção da retirada israelense de todos os territórios árabes. Duas reuniões depois, no final de agosto de 1970, na declaração referente ao vigésimo quinto aniversário da ONU e décimo aniversário da Declaração de Garantia de Independência aos Povos e Países Colonizados, a OUA condenou a "obstinada recusa de forças de agressão de regimes colonialistas e racistas a implementar as resoluções da ONU", mencionando a ocupação israelense do Sinai junto às colônias portuguesas, África do Sul, Zimbabwe (Rodésia) e Namíbia. 
Nos dois próximos encontros ordinários dos chefes de Estado e governo, realizados em setembro de 1970 e junho de 1971 na cidade de Addis Addaba, foram aprovadas duas resoluções sobre a "contínua agressão contra a RAU", após o representante egípcio explanar de forma geral sobre o Oriente Médio e específica sobre seu país. Reafirmando suas resoluções anteriores, a Organização Africana expressou mais duas vezes a solidariedade com a RAU e a "profunda preocupação" com os anos de ocupação de parcela de um "Estado africano irmão", vista como uma "ameaça ao continente africano" e "à paz mundial", e reforçou o pedido de: retirada das forças israelenses dos territórios árabes; apoio dos Estados membros ao representante especial da ONU na região (Gunnar Jarring); e cumprimento pleno da resolução 242.

Na sessão de 1971, a Assembleia da OUA ainda se mostrou preocupada com a ocupação dos territórios de três Estados árabes e consciente dos "esforços construtivos da RAU" para a paz na região (colaboração com a missão de Jarring). Paralelamente, "deplorou os desafios colocados por Israel a essa iniciativa" e condenou esse país pela "detenção arbitrária" de dois cidadãos argelinos, violando as convenções internacionais de aviação civil. A intransigência israelense diante da mediação africana aumentou o apoio à causa árabe. Entre 1971 e 1972, a OUA, de fato, esforçou-se para garantir o cumprimento de suas resoluções anteriores concernentes ao Oriente Médio, incluindo aí uma afirmação da parte de Israel do princípio de não anexação dos territórios ocupados. A organização criou o "Comitê dos Dez", que travou contato com os governos israelense e egípcio. Essa iniciativa de paz foi levada à ONU, mas na visão africana rejeitada por Israel junto aos demais documentos dessa própria organização.

Assim, em sua nona sessão ordinária, a OUA foi bem mais enfática em suas deliberações. Relembrou suas resoluções anteriores e, reafirmando a solidariedade e o apoio a RAU para a recuperação de seus territórios, deplorou a recusa de Israel acatar seus documentos e os da ONU, bem como obstar a missão Jarring. A Organização convidou o governo israelense a declarar publicamente sua adesão ao princípio de não anexação de territórios pela força e a se retirar das áreas ocupadas desde 1967. Convocou, expressamente, todos os Estados membros da Organização a "dar ao Egito toda a assistência" e intensificar suas ações "em fóruns internacionais e na Assembleia Geral e Conselho de Segurança da ONU" para garantir a retirada imediata e incondicional dos territórios ocupados e a condenação de Israel por obliterar a resolução 242 da ONU, que veta a aquisição de territórios pela força. Indo ainda mais longe, "decidiu acompanhar de perto a situação no Oriente Médio", requerendo a todos seus membros que se abstivessem de fornecer a Israel qualquer arma, equipamento militar ou apoio moral, que 
permitisse fortalecer seu potencial militar e manter a ocupação "de territórios árabes e africanos".

Na resolução aprovada no final de maio de 1972, no décimo encontro regular da Assembleia da OUA, a Organização avançou na condenação e ação conjunta para assegurar a retirada israelense dos territórios. Sua atuação pregressa foi decisiva para a aprovação de resoluções da Assembleia Geral da ONU, como a 2799 e a 2949. Esta última pedia o reconhecimento público de Israel do princípio de não aquisição de territórios pela força, a retirada de suas forças e afirmava a ilegalidade e nulidade de suas ações para alterar "o caráter físico ou a composição demográfica dos territórios árabes ocupados". la ainda mais longe, solicitando aos Estados que não reconhecessem as mudanças promovidas por Israel e evitassem ações, incluindo no campo da ajuda, que pudessem constituir um reconhecimento da ocupação.

Em 1973, a posição africana diante de Israel endureceu ainda mais. Contribuiu para essa situação a manutenção da ocupação dos territórios árabes, a contínua atuação egípcia (vista como favorável à paz e que anualmente expôs a situação no Oriente Médio nos encontros da OUA) e a persistente recusa israelense em acatar as resoluções e se empenhar nas iniciativas anteriores da ONU e da própria OUA, como a missão de Jarring e o "Comitê dos Dez" - ambas buscando a efetivação da resolução 242, do Conselho de Segurança da ONU. Em fevereiro, o Conselho dos Ministros reafirmou estar muito preocupado com a situação e condenou a ocupação ilegal dos territórios árabes em contravenção a suas resoluções, da ONU e dos Países Não Alinhados, demandando a retirada israelense imediata e incondicional e o fim dessa situação que "ameaça a paz e segurança internacional". Pela primeira vez, fez uma menção direta à Causa Palestina, afirmando que o "respeito aos direitos dos palestinos é um elemento indispensável para o estabelecimento de uma paz justa e duradoura no Oriente Médio", denunciando a "política expansionista que conduziu ao desenraizamento do povo palestino de sua residência legítima" e prometendo "o seu apoio total à justa causa da luta pela libertação deste povo".

Três meses depois, em maio de 1973, a Assembleia dos Chefes de Estado e Governo da OUA interpretou a situação em termos muito semelhantes, ameaçando sancionar Israel. A ocupação era um "perigo que ameaçava a segurança, integridade territorial e unidade de nosso continente". A deterioração da situação no nordeste da África era "resultado da contínua agressão perpetrada contra territórios árabes e do Egito". Israel continuava rejeitando as resoluções da OUA e da ONU, negava-se a se retirar dos territórios e persistia em sua política de criar fatos consumados para "servir aos seus desígnios expansionistas". O país "obstruía sistematicamente todos os esforços exercidos para alcançar uma solução 
pacífica para o problema, tanto em sua esfera africana quanto internacional". Portanto, em conformidade com os princípios contidos em sua própria carta e na da ONU, a Organização ameaçava adotar medidas políticas e econômicas contra Israel. Nos mesmos termos de suas resoluções referentes à África do Sul, Rodésia e Namíbia, a OUA destacou que, a ajuda militar e econômica massiva de certas potências, além do apoio político e moral prestado, encorajava e possibilitava ao país agredir seus vizinhos, "pedindo com severidade" que elas se abstivessem de amparar Israel. Com base nessa leitura dos fatos, a Organização "condenou veementemente a atitude negativa de Israel, seus atos de terrorismo e a obstrução de todos os esforços voltados a estabelecer uma solução justa e equitativa do problema, conforme a resolução 242 do Conselho de Segurança". O apoio da Assembleia dos Chefes de Estado à legítima luta do Egito para recuperar seus territórios foi definido como "ativo e total" e ela também reconheceu "os direitos inalienáveis do povo da Palestina" em si e como um elemento essencial para a paz.

Nesse quadro de reconhecimento do povo palestino e endurecimento da posição africana relativa a Israel, entre outubro e novembro de 1973, ao passo que a OUA criou um comitê de sete membros para estabelecer contato com a Liga Árabe e definir uma política de cooperação afro-árabe, vinte e um Estados subsaarianos romperam relações diplomáticas com Israel. Agora, de toda a Organização Africana, somente Lesoto, Malaui, Suazilândia e Ilhas Maurício mantiveram contatos oficiais com o Estado sionista. Locksley Edmondson (2010) explica essa reviravolta a partir do desencadeamento da Guerra do Yom Kippur, quando Egito e Síria atacaram Israel tentando recuperar seus territórios ocupados desde 1967, e da crescente "solidariedade afro-árabe-terceiro-mundista". Foi definida uma linha diplomática comum a africanos, árabes e demais povos do Terceiro Mundo, destacando-se a atuação do presidente argelino Boumediene que demonstrou o parentesco entre as lutas de libertação no Oriente Médio e na África Austral, inclusive apontando o estreitamento das relações militares e econômicas entre Israel e o regime de apartheid.

Concomitantemente a esse reconhecimento do povo palestino e isolamento de Israel, em dezembro de 1973, foi aprovada na Assembleia Geral da ONU a resolução 3151 G (XXVIII) denunciando e condenado a coalizão ou "aliança maldita" do "sionismo e imperialismo israelense" com os dois principais alvos de oposição e condenação da OUA: o colonialismo português e o regime de apartheid. Nos termos desse documento, África do Sul, Portugal e Israel se ajudavam mutuamente no âmbito político, militar e financeiro. A proposta de condenar a "aliança maldita" na resolução 3151 G (XXVIII) partiu do representante do Burundi. Nas discussões que antecederam sua aprovação, o representante egípcio argumentou que sionismo, colonialismo e apartheid eram afins, 
enfatizando os laços substanciais entre eles. No encontro plenário 2.201 da Assembleia Geral da ONU ele alegou que, as atitudes portuguesas e sul-africanas durante e após a Guerra do Yom Kippur provaram que "o eixo Tel Aviv-Pretoria-Lisboa é uma realidade", e que há uma "assistência multifacetada". Israel negou esses vínculos, afirmando se tratar a resolução de "uma nova tentativa da máquina de propaganda árabe". De todo modo, a denúncia dessa "aliança" reverberava uma resolução adotada anteriormente pela OUA, na oitava sessão extraordinária de seu Conselho de Ministros.

A resolução 3151 G (XXVIII) foi uma das primeiras ações empreendidas durante e nos termos da Década da Ação para Combater o Racismo e a Discriminação Racial, prevista na resolução 2919 (XXVII) da Assembleia Geral da ONU, de 15 de novembro de 1972, e aprovada um ano depois na resolução 3057 (XXVIII), de forma que seu lançamento oficial coincidisse com o vigésimo quinto aniversário da Declaração Universal dos Direitos Humanos. A partir dessa decisão, a ONU enfatizava sua oposição e predisposição em combater qualquer manifestação de discriminação racial, condenando regimes e governos que baseassem sua política oficial ou prática nela, em particular o "apartheid e políticas semelhantes". Deveriam ser aplicadas medidas em prol da descolonização e da autodeterminação dos povos e os Estados necessitariam adotar medidas para evitar ações de pessoas e grupos, que incitassem "paixões sectárias e racistas" sustentadoras de políticas voltadas a consolidar o colonialismo ou excluir os nativos em reservas. $O$ objetivo era, em um período delimitado, estender os direitos humanos e as liberdades fundamentais a todos, erradicando o racismo e a discriminação racial.

Adotadas já durante a década proclamada pela ONU, as resoluções da OUA em 1974 estiveram no meio caminho entre as críticas gerais a Israel e o reconhecimento inicial da Questão Palestina, em 1973, e as afirmações contundentes contra o "inimigo sionista racista" do ano seguinte. No começo de abril de 1974, o Conselho de Ministros determinou que, além da retirada israelense de todos os territórios ocupados, a paz durável e justa no Oriente Médio dependia da realização dos "direitos nacionais inalienáveis e legítimos do povo palestino". Seu não reconhecimento e a persistência israelense na ocupação eram o motivo da precariedade dos acordos de cessar-fogo, assinados em decorrência da Guerra do Yom Kippur (1973). Ainda nesse encontro, a Organização para Libertação da Palestina (OLP) foi reconhecida como a única representante legítima do povo palestino e de "sua luta heroica contra o sionismo e o racismo". Dois meses depois, no encontro seguinte do Conselho, essas decisões foram ratificadas. Essas reuniões de 1974 também foram importantes para que, a OUA e a Liga Árabe pavimentassem o caminho para a intensificação da cooperação e solidariedade afro-árabe nos anos vindouros, inclusive no 
boicote aos regimes racistas do sul do continente (medida esta já adotada pelos governos árabes, salvo exceções, no final de 1973).

O décimo segundo encontro regular da OUA, em maio de 1975, foi marcado pela radicalização de sua oposição ao sionismo, após "ter estudado os desenvolvimentos da Causa Palestina, a grave situação derivada da ocupação israelense dos territórios árabes, sua usurpação dos direitos legítimos do povo palestino", como restituição de propriedades, retorno e autodeterminação e sua recusa em cumprir as resoluções da ONU. Na ocasião, foram aprovadas duas resoluções: uma geral sobre o Oriente Médio e os Territórios Árabes Ocupados e outra específica sobre a Palestina. Ambas foram apoiadas por ampla maioria, com a abstenção de Gana, Serra Leoa, Senegal e Libéria e a oposição do Zaire. O pronunciamento anual da delegação egípcia foi acompanhado de outros, como a fala da OLP sobre os vários aspectos da Causa Palestina e como a África poderia contribuir com ela.

Além dos princípios e objetivos das cartas da OUA e da ONU, e da reafirmação de todos os documentos anteriores, as ações da Organização Africana em relação ao Oriente Médio foram pautadas pelo "destino comum dos povos árabes e africanos, assim como sua contínua luta por seus direitos, liberdade, paz e independência". A interpretação do conflito se manteve a mesma: a situação médio-oriental se deteriora cada vez mais devido à persistente política israelense de agressão e rejeição da vontade da comunidade internacional. O país ignorava as resoluções da ONU e obstruía "todos os esforços de paz para ganhar tempo e impor fatos consumados" a fim de legitimar a ocupação. Novidade em 1975 foi a menção a novos instrumentos jurídicos como base das censuras da OUA a Israel, como condenações das constantes violações dos direitos internacionais, humanos e humanitários.

Ecoando a decisão tomada no ano anterior pelo Conselho de Ministros, a Assembleia de Chefes da OUA também reconhecia a OLP como único representante legal do povo palestino. Se em 1973, a Assembleia dos Chefes de Estado vinculou a paz à retirada israelense e ao respeito aos "direitos inalienáveis do povo da Palestina", em 1975 definiu esses direitos como "plenos direitos nacionais palestinos à soberania, independência nacional e autodeterminação". Agora a ocupação também violava os "direitos nacionais do povo palestino", "ameaçando seriamente a segurança, a integridade territorial e a soberania dos países e povos árabes". Seu objetivo principal seria a "judaização" desses espaços, alterando suas "características humanas, geográficas e culturais". Isso foi condenado publicamente pela OUA como "expansão agressiva" e "anexação dos territórios árabes pela força". Essa interpretação ainda mais crítica das ações israelenses, que aproximou de vez africanos, árabes e palestinos na luta contra o 
racismo, o imperialismo e as agressões por ele provocadas, levou a OUA a afirmar sua decisão de "adotar medidas práticas e adequadas para enfrentar a contínua agressão e violação do inimigo sionista", como por exemplo, aplicar sanções contra Israel, com base na carta da ONU. O pregresso apoio "ativo e total" ao Egito foi estendido a todos os "Estados da linha de frente" e ao povo palestino em sua "luta legítima para recobrar todos os territórios ocupados e seus direitos usurpados, por todos os meios possíveis". A OUA se comprometeu a apoiar plena e efetivamente os palestinos, inclusive no estabelecimento de sua autoridade nacional independente.

A Causa Palestina foi, literalmente, reconhecida como uma causa africana e a OLP convidada a planejar uma estratégia conjunta com o Comitê de Libertação da Organização Africana. Todos os Estados membros deveriam apoiar os palestinos com todos os meios possíveis em sua luta para restaurar seus direitos nacionais contra o "colonialismo racista sionista". O sionismo fora definido como "um perigo à paz mundial", mantenedor de um "regime racista na Palestina ocupada", que partilharia da mesma origem imperialista e estrutura racista dos regimes na África do Sul e no Zimbabwe, aos quais estaria "organicamente vinculado em suas políticas de repressão da dignidade e integridade do ser humano". Diante disso, adotando o mesmo encaminhamento que fez em relação à África do Sul e ao apartheid anos antes, a OUA decidiu organizar uma campanha informativa para desmascarar "a natureza racista e agressiva da entidade sionista", bem como sua propaganda voltada a despertar a hostilidade do mundo contra árabes e africanos.

As duas reuniões do Conselho dos Ministros ocorridas em 1975 também evidenciam a radicalização da OUA em sua oposição ao sionismo. A "situação deteriorante e explosiva no Oriente Médio" decorreria da "atitude israelense agressiva e intransigente" e de suas ambições expansionistas, "prejudicial para a causa da paz, não só na área, mas também em todo o mundo". Identificado como plenamente responsável por retardar qualquer progresso em direção a uma paz justa, e denunciado por rejeitar as resoluções da ONU, Israel foi "severamente condenado" pela continuidade da ocupação, "negação da existência e dos direitos do povo árabe da Palestina e agressões contra o Líbano e o povo palestino". A Organização Africana considerou salutar o estabelecimento de representações palestinas nas capitais de seus Estados membros, para que, por meio do contato permanente com seus governos, a luta pela edificação do "futuro Estado do povo palestino" fosse fortalecida. Paralelamente, todos os Estados deveriam cessar de prestar qualquer forma de ajuda militar a Israel, o que só consolidaria a ocupação e dificultaria o processo de paz.

Na primeira das reuniões do Conselho de 1975, além da resolução, foi feita uma declaração específica sobre a Palestina e o Oriente Médio, responsabilizando as "ambições 
racistas e expansionistas" do sionismo pela instabilidade regional. Israel estava "provocando e agredindo" o Líbano, desdenhando assim dos esforços da comunidade internacional para o estabelecimento da paz e dos "valores humanos e resoluções e tratados internacionais". O país foi "veementemente condenado" não só pela ocupação a partir da Guerra dos Seis Dias, mas "pelos atos de agressão nos últimos vinte e oito anos" (desde 1947, quando a ONU adotou a resolução 181, sugerindo a partilha da Palestina). A declaração aponta alguns exemplos, destacados na sequência. $O$ tratamento da população palestina, que é "retirada de suas casas, sujeitada à 'opressão e repressão racista', privada de seus direitos, expulsa de suas terras e têm suas casas destruídas por meio dos mais detestáveis métodos nazistas". A "alteração das características políticas, econômicas, culturais, demográficas e administrativas da Palestina, dos territórios árabes ocupados e locais sagrados de uma forma sem precedentes nos anais da história, mesmo nos mais brutais regimes colonialistas". "Os ataques contínuos sobre a população desarmada e inocente de refugiados palestinos vivendo em campos nos Estados árabes vizinhos, particularmente no sul do Líbano. Esses ataques são reminiscentes das atrocidades bárbaras da Idade Média". A demolição de vilas e cidades árabes e a detenção de milhares em "campos de concentração e prisões sem provas".

O teor dessa declaração do Conselho dos Ministros da OUA sobre a Palestina e o Oriente Médio, em 1975, demonstra que foi quase inevitável para a Organização decidir aplicar as sanções estipuladas pela ONU contra países que infringissem continuamente suas resoluções - acaso quisesse manter a coerência com os princípios de sua própria carta e seu comprometimento declarado na luta contra o colonialismo e o racismo. A possibilidade de sanções já havia sido anunciada no encontro dos Chefes de Estado e Governo, em maio de 1975. Além dos princípios de ação que aproximavam por si só a entidade da luta palestina, de 1973 em diante houve uma cooperação e solidariedade cada vez maior entre os países africanos e árabes. Se de um lado era manifesto e crescente o apoio africano à luta palestina, por outro era solicitado aos Estados da Liga Árabe que reconhecessem os movimentos de libertação africanos legítimos aos olhos da OUA e, se possível, permitissem o estabelecimento de escritórios em suas capitais e garantissem a condição de observadores nas reuniões da Liga Árabe.

Desdobramento dessa evolução da Questão Palestina no seio da OUA foi o apoio maciço dos países africanos à resolução 3379 da Assembleia Geral da ONU, aprovada em 1975, que considerou o sionismo uma forma de racismo. Assim como a resolução $3151 \mathrm{G}$ (XXVIII), que em 1973 condenou a aliança entre sionismo, apartheid e colonialismo português, essa nova medida foi adotada durante a Década da Ação para Combater o Racismo e a Discriminação Racial e em consonância com seus objetivos declarados. 


\section{Conclusão}

Muito além de meramente reconhecer as naturezas afins das tensões na Palestina, Oriente Médio e África, a OUA buscou atuar ativamente para solucionar essas questões, visto constituírem um "problema primeiramente africano". As duas superpotências (EUA e URSS) não deveriam permanecer as únicas partes a tratar desses impasses, sendo "um direito e dever africano desempenhar um papel construtivo nos esforços de estabelecer uma paz justa e duradoura no Oriente Médio". Dado a "unidade da luta de libertação na África e no mundo todo", enquanto o Egito e a OLP manteriam a OUA informada sobre os desdobramentos na região, a Liga Árabe e o Comitê de Libertação da África deveriam se consultar para delinear a melhor estratégia para a libertação dos territórios ocupados por Israel, nos moldes daquela já adotada na África. O Comitê de Libertação deveria assistir a OLP e envidar contínuos esforços dentro da OUA e da ONU "para encontrar os caminhos e meios mais eficazes para aumentar o isolamento político e econômico israelense em nível internacional, enquanto o país persistisse em sua política racista, expansionista e agressiva".

Esses seriam "os sentimentos da África" em relação à Palestina e ao Oriente Médio, baseados nos princípios das cartas da OUA e da ONU, assim como na Declaração Universal dos Direitos Humanos. Aos olhos da Organização Africana, assim como deveriam fazer em relação à África do Sul e Portugal "os países do mundo amantes da paz" tinham o dever de boicotar Israel. Ecoando as palavras de Kodjo e Chanaiwa (2010, p. 921), "o parentesco, entre o racismo na África do Sul e o sionismo na Palestina e nos territórios ocupados, uniu as vítimas destas duas práticas, os africanos e os árabes".

\section{REFERÊNCIAS}

ASANTE, S. K. B.; CHANAIWA, David. O pan-africanismo e a integração regional. In: MAZRUI, A. A.; WONDJI, C. História geral da África, VIII: África desde 1935. Brasília: UNESCO, 2010.

CHANAIWA, David. A África Austral. In: MAZRUI, A. A.; WONDJI, C. História geral da África, VIII: África desde 1935. Brasília: UNESCO, 2010.

EDMONDSON, Locksley. A África e as regiões em vias de desenvolvimento. In: MAZRUI, A. A.; WONDJI, C. História geral da África, VIII: África desde 1935. Brasília: UNESCO, 2010.

HRBEK, Ivan. A. A África setentrional e o chifre da África. In: MAZRUI, A. A.; WONDJI, C. História geral da África, VIII: África desde 1935. Brasília: UNESCO, 2010. 
KODJO, Edem; CHANAIWA, David. Pan-africanismo e libertação. In: MAZRUI, A. A.; WONDJI, C. História geral da África, VIII: África desde 1935. Brasília: UNESCO, 2010.

KOUASSI, Edmond Kwam. A África e a Organização das Nações Unidas. In: MAZRUI, A. A.; WONDJI, C. História geral da África, VIII: África desde 1935. Brasília: UNESCO, 2010.

MAZRUI, Ali. A. "Procurai primeiramente o reino político". In: MAZRUI, A. A.; WONDJI, C. História geral da África, VIII: África desde 1935. Brasília: UNESCO, 2010.

NALDI, Gino J. The Organization of African Unity: an analysis of its role. London: Mansell Publishing Limited, 1989.

OWUSU, Maxwell. A agropecuária e o desenvolvimento rural. In: MAZRUI, A. A.; WONDJI, C. História geral da África, VIII: África desde 1935. Brasília: UNESCO, 2010.

SESAY, Amadu; OJO, Olusola; FASEHUN, Orobola. The OAU after twenty years. London: Westview Press, 1984.

Fontes

AFRICAN UNITY ORGANIZATION. Resolutions of the Assembly of the Heads of States and Governments. Disponível em: <http://webmail.africaunion.org/OAU\%20Decision/OAU\%20Assembly\%20of\%20Heads\%20of\%20State\%20and\%20Govt\%20Decision \%20 E.html>. Acesso em 13 mar. 2013.

AFRICAN UNITY ORGANIZATION. Resolutions of the Council of Ministers. Disponível em: $<$ http://webmail.africaunion.org/OAU\%20Decision/OAU\%20Council\%20Decision\%20 E files/OAU\%20Council\%20Decision\%20Wor d\%20 E.htm>. Acesso em 13 mar. 2013.

ORGANIZATION OF AFRICA UNITY. Resolutions and declarations adopted by the fourth ordinary session of the Assembly of heads of state and government held in Kinshasa, Congo, from 11 to 14 september 1967. Addis Ababa: Organization of African Unity, 1967. Disponível em: <http://www.africaunion.org/official documents/Heads\%20of\%20State\%20Summits/hog/eHoGAssembly1967.pdf>. Acesso em 26 fev. 2013.

UNITED NATIONS. General Assembly resolutions. Disponível em: <http://www.un.org/documents/resga.htm>. Acesso em 4 fev. 2013. 